\title{
A Reflection on African Religious Life Through the 21 Conferences of "L'Africa Romana" (1983-2020)
}

Paola Ruggeri

\section{Università degli Studi di Sassari}

ruggeri@uniss.it

Fecha recepción 26/04/2021 | Fecha aceptación 13/09/2021

\section{Abstract}

The international conferences of "L'Africa romana", organized by the University of Sassari since 1983, are the most important events of the last forty years, regarding the history, archaeology and epigraphy of North Africa; they have given the opportunity to well-established and young scholars alike, from dozens of countries, to compare their experience and knowledge. The result is a new vision of the Roman provinces of Africa, due to the presentation of a considerable amount of unpublished material.

\section{Résumé}

Les Colloques internationaux de "L’Africa romana", organisés par l'Université de Sassari depuis le 1983, représentent pour les derniers quarante ans la nouveauté la plus important dans les domaines de l'histoire, de l'archéologie et de l'épigraphie de l'Afrique du Nord ; ils ont donné la possibilité aux savants expérimentés et aussi aux collègues plus jeunes de dizaines de pays de confronter leurs expériences et leurs connaissances. Le résultat a été une vision renouvelée des provinces africaines en époque romaine, même dans le domaine de la 
The African provinces, although included in the Mediterranean koinè, have been regarded in their specific characteristics, paying due attention to the essential local religious strata, to the internal and external non-religious aspects of the cult and to the original merging of said elements in the religious life between the Atlantic Ocean and the Gulf of the Great Sirte. Ever since the first conferences it was decided to overcome the ethnocentric view, remnant of the colonial past, and underline how in the African provinces local and imported divinities have come together. The present contribution proposes a first annotated bibliographic overview of the works that involved Universities, Research Centers, Agencies for the Development Heritage and Scientific Societies who carried out international research by comparing methods and going beyond a traditional view that was incapable of understanding the ancient world in depth.

\section{Keywords}

L'Africa Romana, Conferences, Religious Life, Bibliography Annotated religion, grâce aussi à la publication de beaucoup de matériel inédit. Les provinces africaines, bien que intégrées dans la koiné méditerranéenne, ont été considérées dans leur spécificité, avec une attention aux substrats religieux locaux essentiels et aux agents cultuels, aux mélanges et aux résultats souvent originaux que tout cela a eu dans la vie religieuse entre l'Atlantique et la Grande Syrte. À partir des premières Conférences le but était de dépasser totalement l'idée d'une vision ethnocentrique, héritage d'un passé colonial, pour souligner comment dans les provinces africaines les dieux locaux ont souvent "parlé » et trouvé un «lien " avec les dieux importés des autres provinces de l'empire. Cette contribution représente une première bibliographie commentée des travailles des Universités, des Centres de recherche, des Instituts de tutelle et de mise en valeur, des Sociétés scientifiques qui ont menés les recherches au niveau international, en comparant les méthodes et en dépassant une vision traditionnelle incapable de comprendre le monde antique en profondeur.

\section{Mots-clés}

L'Africa Romana, Conférences, vie religeuse, bibliographie annotée 
If YOU OBSERVE CLOSELY ENOUGH the successful series of conferences called L'Africa Romana (which started in 1983 and has reached its $21^{\text {nd }}$ edition so far), you will realize the it has an original fundamental component which has been represented by the consideration of religious aspects, illustrated by the Mediterranean relations, from the Punic phase to the Roman age, up to the late Roman Empire. Over the years, all this has led to several in-depth studies (on different geographical and diachronic levels) on the connections between provinces and local cults integrated into the Roman world, from the analysis of the sacerdotes and their relationship with social classes and traditions regarding urban areas or families to that on the imperial cult of ancient Rome, from the complex phenomenon of "syncretism" to the topic of legacy and persistence.

The first conference of L'Africa Romana series, commissioned by Attilio Mastino, took place in December 1983 with the participation - among others - of Marcel Le Glay, a distinguished master and unsurpassed scholar of African Saturn, who held a conference on December 16 at the Chamber of Commerce, Industry and Crafts in Sassari on "La vie religieuse de l'Afrique romaine dans le II siècle après J.C.", followed by a debate with the participation of Sandro Schipani, Ammar Mahjoubi ("Les cultes paiens dans la region de Vaga, Beja"), Hédi Slim ("Les cultes paiens à Thysdrus") and Giancarlo Susini. The content of that day's work although at a later date - was published in the first volume of L'Africa Romana. Le Glay later participated in many other Conferences and begun to examine magic in the ancient world, to which he dedicated two articles in L'Africa Romana. His intention was to have them published in a summary volume by starting with Tripolitania and its relationship with the East and above all by mentioning several times his Algeria as he did in his communication made in Cagliari in 1990 on religious syncretism in the colony of Thamugadi, with reference to the cults of the goddess Africa, of Aesculapius and Serapis in the sanctuary of Aqua Septimiana, on occasion of the $8^{\text {th }}$ conference (67-78). His contribution to our conferences is well summarized in LAfrica Romana X (53-62), with particular attention to the texts which he then regularly delivered to the press and which appeared in various volumes, together with the article dedicated to the reexamination of four African inscriptions: from Caesarea, Furnos 
Maius and Lambaesis, published in the $5^{\text {th }}$ volume ("A propos de quelques textes africains", 132-140), where - among other topics - the dedication to the Sun placed in Lambaesis by the legate of the legio III Augusta, is of great interest. On each of these occasions Le Glay presided over the working sessions and actively participated in the debate; he made a fundamental contribution to introduce innovations in the adopted terms of speech and to define new interpretative categories, which have definitely shaped the subsequent meetings.

Giancarlo Susini wrote in the conclusion of that distant first conference:

"For this reason too, the organizers of this conference did well to dedicate half of the day, part of the meeting itself to religious phenomena, precisely because religious phenomena with their palimpsests and their inextricable and compelling doubts, with their interpretations and syncretisms and the enthusiasm they still raise nowadays, and their meaning which is still puzzling are able to represent the significance of ancient cultures more than ever, as a mirror to the history of the development of peoples who once faced and still overlook the Mediterranean basin. The masterful lesson of Professor Le Glay and the extremely interesting counterpoint of our colleague Mahjoubi have really brought us to the heart of an exciting research, which does not end in controversy (far from it), but is revived in the seriousness of the commitment, the very scientific nature of the document, in its fascinating exegesis and its explanation. It almost occurred to me to think, while prof. Le Glay was speaking and was just concluding his lesson that investigating on the filaments and on the factors of ancient religion and above all of the religion of the Romanized world is the only way to understand what was perhaps the most powerful arcanum of the Roman world and its development" (transl. by the author).

With the $2^{\text {nd }}$ Conference on December 16, 1984, the Antiquarium Turritano was inaugurated in Porto Torres. A small museum with a marble altar of the Egyptian Bubastis in the center built and dated to the end of the age of Tiberius, that Marcel Le Glay a year earlier had been able to study in the warehouses of the Museo Nazionale G. A. Sanna di Sassari (see A. Boninu, II, 241-250; M. Le Glay, in A. Boninu, M. Le Glay, A. Mastino, Turris Libisonis colonia Iulia, Sassari, 1984, 105-116). In recent years unpublished information has been acquired on the urban development by comparing the studies of some of the most qualified scholars on the problems of cataloging, filing, commenting and publishing some African epigraphic collections. They examined the relationship between cities and the countryside, commercial traffic, ports, roads, religious life, the movement of legions and auxiliary cohorts, the phenomena of social mobility in North Africa with its repercussions, contacts, the connection to Sardinia in the imperial age within the framework of the relationship between center and periphery.

The 21 volumes (about 50 tomes) of L'Africa Romana together with several publications in the series of the Department of History and other collections that have come to life in parallel (Studi di Storia antica e di Archeologia, Collana della Scuola archeologica italiana di Cartagine, etc.) contain very complex studies, ranging from general syntheses to specific interventions on single territories, on single divinities and on single monuments. Numerous collections have proven to be extremely useful, such as those of Attilio Mastino on epigraphic research in Tunisia (I, 73-128), in Algeria (III, 113-166), in Morocco (IV, 337- 
384), which have led to some reflections on the inscriptions documenting African religious life, which have been compared to other provincial features, in order to better highlight the local particularities and the vitality of indigenous cults. See more in the recent review of the first thirty years of the Conference: Alessandro Campus, "L'Africa romana per l'epigrafia punica: trent'anni di ricerche” (XX, 947-954); Solenn de Larminat, “1983-2013: trente ans d'archéologie funéraire dans L'Africa romana" (XX, 835-844); see also Cinzia Vismara, "Pour une archéologie funéraire d'époque romaine en Afrique (Proconsulaire, Byzacène, Tripolitaine, Numidies, Maurétanies)" (XX, 845-854). A general reflection on issues related to religious life has already been developed by Valentino Gasparini, in "L'Africa romana, laboratorio di mutazioni religiose. Nuove prospettive su preferenze individuali e spazi di negoziazione" (XX, 923-930), who stated the following:

"North Africa is today more than ever a very fertile ground for the study of the history of religions. In contrast to the previous period which was characterized by sporadic monographs of regional (Tripolitania, for instance) or local areas of interest (Carthage, first of all) over the last few years numerous thematic works have been advanced, dedicated to individual cults, divinities and epithets (Caelestis, Cerere, Esculapio and Hygieia, Frugiferous, Neptune, Isiac, Metroacian and Mithraic cults, Saturn, Tellus and other Italic divinities, as well as the imperial cult and Christian and Jewish religions). The historiographical aspect of the research concerning the religious pluralism of Roman Africa has thus been enriched exponentially, showing the extreme variety of its nuances".

Some fundamental volumes for our studies have appeared in recent years (A. Cadotte, La Romanisation des Dieux. L'interpretatio romana en Afrique du Nord sous le Haut-Empire, Religions in the Graeco-Roman World 158, Leiden and Boston 2007, yet

"what has been lacking (and which still continues to be absent) above all is an updated holistic and synthetic approach to the religious panorama of Roman Africa. Here, as elsewhere, the process of religious transposition can only be understood as a historical and cultural phenomenon. This requires first of all the reconstruction of the socio-political context through the analysis of the different conditions and circumstances relating, for example, to the territorial organization and the institutional and administrative structure" (924) (transl. by the author).

We could mention many other volumes and reviews: eg. the report by Sabine Fialon, "Antiquité tardive et christianisme africain dans L'Africa romana: un bilan historiographique" (XX, 1145-1184) is dedicated to the topic of the relationship between paganism and Christianity. These are just examples of single insights, which testify to the richness of the topic under consideration and may be examined roughly for major topics.

The $1^{\text {st }}$ Conference held in Sassari between 16 and 17 December 1983 was dedicated to the study of the Romanization of North Africa with particular regard to the origins, various topics related to conservation and persistence, the vitality of the Libyan-Punic project and the richness of religious life, which made it possible to observe the relationship of a fruitful syncretism between a lively tradition and the Roman culture that arrived subsequently. 
The $2^{\text {nd }}$ Conference (Sassari 14-16 December 1984) was aimed at the study of the relation between Africa and Sardinia in Roman times: the function of a "bridge", which Sardinia had from the end of the Republic to the Vandal age between the Roman and the Carthaginian culture connecting Africa and Europe. Through a series of data collected for the first time in a coherent form, the inquiry of the Mediterranean centrality of Sardinia and its function as a link to Africa was affirmed.

The $3^{\text {rd }}$ Conference (Sassari 13-15 December 1985) was dedicated to the epigraphic documentation and to the history of the Roman provinces of the Maghreb. The event displayed an abundant quantity of previously unpublished material. Since this edition, the High Patronage of the President of the Republic has been constantly granted.

The $4^{\text {th }}$ Conference (Sassari 12-14 December 1986) was dedicated to L'epigrafia e la storia delle province romane del Magreb.

The $5^{\text {th }}$ Conference (Cagliari-Sassari, 11-13 December 1987) was also dedicated to Lepigrafia e la storia delle province romane del Magreb, with an increasing number of foreign scholars from ten different Mediterranean countries. Since this edition, the patronage of the Association Internationale d'Epigraphie Grecque et Latine has been frequently granted.

The $6^{\text {th }}$ Conference (Sassari-Alghero, 16-18 December 1988), was dedicated to L'Africa e la Sardegna in età tardo-antica, with a special session dedicated to St. Augustine.

The $7^{\text {th }}$ Conference, dedicated to Sopravvivenze puniche e persistenze indigene nel Nord Africa ed in Sardegna in età romana was held in Sassari between 15 and 17 December 1989.

The $8^{\text {th }}$ Conference, dedicated to Economia e società nel Nord Africa ed in Sardegna in età imperiale: continuità e trasformazioni took place in Cagliari between 14-16 December 1990.

The $9^{\text {th }}$ Conference, dedicated to Nuove scoperte epigrafiche nel Nord Africa ed in Sardegna, was held in Nuoro and Orosei between 13-15 December 1991.

The $10^{\text {th }}$ Conference (Oristano, 11-13 December 1992), was held on the topic of Civitas: l'organizzazione dello spazio urbano nel Nord Africa ed in Sardegna.

The $11^{\text {th }}$ Conference (Carthage, Tunisia, 15-18 December 1994) dealt with the following topic: La scienza e le tecniche nelle province romane del Nord Africa e nel Mediterraneo and was promoted in agreement with the International Centro per lo studio della nozione di spazio e di tempo (CISST) of Brugine (PD) and with the Istituto di Studi e Programmi per il Mediterraneo (ISPROM) of Sassari.

The $12^{\text {th }}$ Conference (Olbia, 13-15 December 1996) was dedicated to L'organizzazione dello spazio rurale nelle province del Nord Africa e nella Sardegna.

The $13^{\text {th }}$ Conference (Djerba, Tunisia, 10-13 December 1998), elaborated on the topic Geografi, viaggiatori, militari nel Maghreb: alle origini dell'archeologia nel Nord Africa.

The $14^{\text {th }}$ Conference (Sassari, 7-10 December 2000), was dedicated to Lo spazio marittimo del Mediterraneo occidentale: geografia storica ed economia.

The $15^{\text {th }}$ Conference (Tozeur, Tunisia, 12-15 December 2002) was dedicated to the theme Ai confini dell' impero: contatti, scambi, conflitti. The Conference, organized by the Department of History and the Center for Interdisciplinary Studies on the Roman Provinces of the University of Sassari, in collaboration with the Institut National du Patrimoine of Tunis, was promoted with the patronage of the Ministry for Foreign Affairs, the Ministère des Af- 
faires Etrangeres of Tunis, the Ministère de la Culture of Tunis and the Association Internationale d'Épigraphie Grecque et Latine. Furthermore the Governor of the Tozeur Region, the Italian Institute for Africa and the Middle and Far East, the Department of Archaeological and Historical-Artistic Sciences of the University of Cagliari, and the Archaeological Superintendencies of Sardinia also collaborated on the project.

The $16^{\text {th }}$ Conference (Rabat, Morocco, 15-19 December 2004) was dedicated to the Mobilità delle persone e dei popoli, dinamiche migratorie, emigrazioni ed immigrazioni nelle province occidentali dell'impero romano. Various topics such as the mobility of people, population exchanges between provinces, rural populations, nomadism, contacts and conflicts were taken into consideration. The Conference, organized by the Department of History and the Center for Interdisciplinary Studies on the Roman Provinces of the University of Sassari, was held in collaboration with the Institut National des Sciences de l'Archéologie et du Patrimoine of Rabat and with the Faculté des Lettres de l'Université Hassan II de Mohammedia. The Conference was promoted with the patronage of the Ministry for Foreign Affairs, the Ministère des Affaires Etrangères, the Ministère de la Culture, the Ministère de l'Éducation Nationale, de l'Enseignement Supérieur, de la Formation des Cadres et de la Recherche Scientifique, of the Association Internationale d'Épigraphie Grecque et Latine (AIEGL), of the Istituto di Studi e Programmi per il Mediterraneo (ISPROM) and the Sardinian Regional Department of Tourism.

The $17^{\text {th }}$ Conference (Sevilla, Spain, 14-17 December 2006) was dedicated to the Le ricchezze dell'Africa. Risorse, produzioni, scambi, promoted in agreement with the Consejeria de Cultura de la Junta de Andalucia and the Universidad de Sevilla. Topics such as production, trade, navigation and ornatus civitatis were discussed. The conference was organized by the Department of History and the Center for Interdisciplinary Studies on the Roman Provinces of the University of Sassari, in collaboration with the Universidad de Sevilla and the Consejería de Cultura of the Junta de Andalucía. The Department of Humanities and Antiquity of the University of Sassari, the Department of Classical Philology, Glottology and Historical Sciences of Antiquity and the Department of Archaeological and Historical-Artistic Sciences of the University of Cagliari, Archaeological Superintendencies of Sardinia and the Italian Cultural Institute at the Embassy of Italy in Madrid also collaborated.

The $18^{\text {th }}$ Conference (Olbia, 11-14 December 2008), with the participation of about 300 scholars addressed the topic I luoghi e le forme dei mestieri e della produzione nelle province africane, with reference to the economic aspects, salaries, artistic features and craftsmanship, techniques, work tools, professional associations and buildings of production plants included in urban planning of cities.

The $19^{\text {th }}$ Conference (Sassari, 16-19 December 2010) was dedicated to the Trasformazione dei paesaggi del potere nell'Africa settentrionale fino alla fine del mondo antico.

The $20^{\text {th }}$ Conference (Alghero, 26-29 September 2013) was dedicated to Momenti di continuità e rottura: bilancio di trent'anni di convegni L'Africa romana.

The $21^{\text {st }}$ Conference (Tunis, 6-9 December 2018) examined the L'epigrafia del Nord Africa: novità, riletture, nuove sintesi on the initiative of the Department of History, Human Sciences and Education, $\mathrm{PhD}$ on Archeology, History, Human Sciences, Center for Inter- 
disciplinary Studies on the Roman Provinces, the Italian Archaeological School of Carthage (SAIC) and the Academic and Ministerial Institutions of Tunisia, with the support of the Embassy of Italy and the Italian Institute of Culture.

The $22^{\text {nd }}$ Conference of L'Africa Romana was scheduled for 2021 in Tunisia. The ongoing health emergency has prompted the organizing committee to postpone, pending a future improvement in the pandemic situation.

Almost all the conferences have provided for a session dedicated to religious life (even the $21^{\text {st }}$ Conference, Tunis 2018, with about twenty communications), following the original scheme, but also expanding the examination from the Phoenician Punic age (already introduced in the $5^{\text {th }}$ volume by Jean-Paul Rey-Coquais, "Sur une comparaison du clergé phénicien et du clergé 'africain”, V, 397-402) to the Imperial, the Vandal and Byzantine age; from Morocco to Algeria, from Tunisia to Libya, including Greek Cyrenaica on occasion.

If we look at the entire series of conferences, we can observe a progressive geographical widening of the subject area: here we set our limit in the current area of Maghreb, but the other conferences have often focused on the connections and relations with the western provinces, in particular with the Iberian Peninsula, Gaul, Sardinia, Sicily, Corsica, Pantelleria, Malta etc.

If we focus on North Africa there is plenty of news on the Moorish Gods or on Aulisua: the discovery of an altar consacrated deo sancto Aulisuae in Volubilis on the initiative of Sutor Valerius Victor libertus Turnonis, now allows us to specify the indigenous character of a cult which was widely attested to the eastern borders of Mauretania Tingitana; the date of the dedication - August 21 - likely binds it to the Consualia, the feast of the archaic Roman god Consus and in some way to the African Saturn; the latter is honored precisely in Volubilis with a silver statue (Maurice Lenoir, "Aulisua, dieu maure de la fécondité", III, 295-302).

The African god par excellence, Saturn, is widely remembered in Africa Proconsularis, in Numidia (in particular in Idicra, Diana Veteranorum, Hippo, Theveste) and in Mauretania (Caesarea). The list of animals offered in sacrifice to the god could keep traces of an ancient Semitic rite, even if proto-Berber interpretations may not be excluded. More recently the Punic legacies in relation to Baal Hammon have been explored, also on a linguistic level (M'hamed Hassine Fantar, "Du libyco-punique au latin", XXI, 355360; Luis Alberto Ruiz Cabrero, “"Non potevo fumare l'erba sul prato di mio padre». La supervivencia del molk en el África Romana”, XX, pp. 185-196). The major archaeological news of the cult of Saturn was presented by Patrizio Pensabene in Thugga ("Il tempio di Saturno a Dougga e tradizioni architettoniche di origine punica”, VII, 251-293), Zeineb Benzina Ben Abdallah ("Année de sacerdoce ou plutôt ère locale? À propos de deux ex -voto à Saturne récemment découverts dans le saltus Burunitanus", XIII, 1505-1511), Nacera Benseddik among Timgad, Rusippir and Calceus Herculis ("Deo patrio Saturno genitori augusto sacrum. Iconographie du couple en Afrique”, XVI, 1785-1788), Fathia M'charek (“Un temple à Saturne à Furnos Maius", XVII, 2243-2252) and Bruno D'Andrea ("Il tofet di El Kénissia e il rapporto tra tofet tardo punici, santuari a Saturno e 'paesaggi del potere”, XIX, 2479-2496). See also Naidé Ferchiou, "Un sanctuaire de sommet à Furnos Maius, note préliminaire”, XVII, 917-933 and Juan Lewis: “Agnus vicarius. A Substitute for Child 
Sacrifice?", XXI, 395-401. Also the article by Sergio Ribichini, "Il dio El a Leptis Magna: comparative notes", XV, 1557-1564 reminds us of this cultural layer.

The cult of Caelestis also represents many connotations in its relationship with Tanit and Iuno from Carthage to Theveste and Caesarea: Silvia Bullo, "La dea Caelestis nell'epigrafia Africana", XI, 1597-1628; Silvia Bullo, "Echi di tradizioni orientali nel santuario di Caelestis a Cartagine", XVII, 893-905; up to the Iberian peninsula: Antonio Rodriguez Colmenero, "Africae Caelestis en Lucus Augusti. Aportaciones complementarias a la misión de Saturninus Augusti libertus", XII, 1195-1204. The goddess Africa, honored in Thamugadi with the dedication of an ivory statue of Eros, possibly the work of Phidias was however imported from Athens to the indigenous Genius, protector of the province or of some localities: Fabiola Salcedo Garcés, "Estilo africano y estilo áulico en la imagen de Africa", XI, 1091-1102.

Evidently also the deities of the greco-roman pantheon undergo a phenomenon of syncretism: this is the case of Iuppiter, at Sitifis associated with Iuba, the Genius Vanisnesi and the dii Ingirozoglezim (CIL VIII 20627), but also of Ceres (in Carthage with the ancient coroplasty with the representation of Ashtart, see Zohra Chérif, "Les figurines en terre cuite de Carthage: art et authenticité", XI, 1073-1084, Hippo and Caesarea), of Aesculapius (Theveste and Lambaesis), of Hercules-Melqart at Hippo, protector of the Sabuianenses, of the Magna Mater, occasionally confused with Tanit-Caelestis than with Cybele.

As for Iupiter, see Maria Milvia Morciano, "Il culto capitolino in ambito non urbano", XII, 287-291; Camilla Campedelli, "La strana vicenda di una statua di Iuppiter Optimus Maximus in Mustis (Tunisia)", XX, 1375-1380; Lamia Ben Abid, "Note sur l'origine des cartons dans les ateliers de sculpture: Jupiter sur les reliefs de la Tunisie centrale”, XVIII, 815-833.

As for Silvanus, see Abdelaziz Bel Faïda, "Le cult de Silvain en Afrique romaine: témoignages épigraphiques", XV, 1343-1354.

As for Pluto, see Édward Lipinski, "Pluton, hypostase chthonienne de Baal Hamon?", VII, 245-250.

As for Neptunus africanus, see Paola Ruggeri, Salvatore Ganga, "Il tempio di Nettuno a Thignica e la colonizzazione di Thugga e Thubursicum Bure sotto Gallieno", XXI, 73-91.

The cult of Apollo is studied throughout North Africa, even from Cyrenaica. See the contribution of André Laronde, "Prêtres d'Apollon à Cyrène au IIr siècle ap. J.-C.", IV, 469-484. A review of fifty years of Italian excavations: Serena Ensoli, "Per i cinquant'anni di attività della Missione Archeologica Italiana a Cirene: il Santuario di Apollo sulla Terrazza della Myrtousa (1957-2007) with an annotated bibliography", XVII, 2355-2382. André Laronde extends the search related to religious life in Cyrenaica to the priestesses of Hera: "Prêtresses d'Héra à Cyrène" (V, 279-286). Plenty of news come from western Mauretania that concern a whole series of deities (indigenous and classical) and the imperial cult. It is known that there are two Tingitan inscriptions that preserve the following dedication: dis deabusque secundum interpretationem oraculi Clarii Apollinis, one from Banasa (IAMar., 84) and another from Volubilis (IAMar., lat. $344=A E$ 1976, 782); these are most likely dedications made on the advice of the oracle of Apollo Clarius on the initiative of the imperial court, coinciding with the illness contracted by Caracalla during the campaign against the Alamanni in 213. 
As for Dionysus, see Fabiola Salcedo Garcés, "La crátera de Timgad: iconografías del dionisismo en Africa”, XIII, 1837-1843.

As for Liber Pater, see Ahlem Jalloul Boussaada, "Le culte de Liber Pater en Afrique, à la lumière de l'épigraphie", IX, 1049-1065. The relationship between Liber Pater, Dionisus/Bacchus and Shadrapha is investigated by Nedjma Serradj-Remili, "Une nouvelle lecture de quelques inscriptions latines d'Algérie à la lumière de mosaïques dionysiaques", XXI, 579-591.

An overview of the college of dendrophori and the cult of the Magna Mater is offered by Filippo Boscolo, "Le attestazioni epigrafiche dei dendrofori in Africa", XVIII, 309-332.

For the goddess Venus with her epithets of Erycina and Marina, see Raimondo Zucca, "Venus Erycina tra Sicilia, Africa e Sardegna”, VI, 771-779; Noé Villaverde Vega, "Nuevos datos arqueológicos de Rusaddir (Melilla): un santuario de Astarté-Venus Marina en Plaza de Armas", XV, 1837-1875. The various iconographies on mosaics can also be significant for the divine physiognomy of Venus: Isabel Chacón Del Pino, "Reflexiones acerca de la representacion del navio en el mosaico del navigium Veneris de Volubilis", XVII, 521-534; Naïma Abdelouehab, Naïma Smati, "La redécouverte d’une mosaïque de Vénus au Musée des Antiquités d’Alger", XIII, 1783-1787; María Pilar San Nicolás Pedraz, "Interrelación del tipo iconográfico de Venus armada en los mosaicos romanos de África, Hispania y Chipre”, XVI, 133-152.

For the archeology and iconographic representations of Hercules see: Mohamed Habibi, "A propos du temple H et du temple de Melkart-Héraklès à Lixus", X, 231-241; Sergio Aiosa, "Urbanistica e ideologia: a proposito del Tempio di Ercole a Sabratha", XIX, 311-324; Elena Moreno Pulido, "Melqart-Herakles nella monetazione mauritana”, XX, 821-834.

As for Mercurius, see Paola Zanovello, "Produzione e commerci: aspetti del culto di Mercurio nel Nord-Africa romano", XVII, 793-810.

As for Ceres, see Nora Bouhadoun, "Une prêtresse de Cérès à Madaure”, XXI, 415-423; Sihem Aloui Naddari, "Cérès et céréaliculture à travers le secteur méridional du Haut Tell tunisien”, XVII, 935-949.

As for Marsyas, see M'hamed Fantar, "Le mythe de Marsyas sur deux nouvelles mosaïques de Tunisie", IV, 151-166.

For the dense mythological plot and the divine genealogy on Perseus see Guadalupe López Montegudo, "Perseo, viajero a Occidente. Documentos musivos", XIII, 145-157.

Also on Tellus see Sihem Aloui Naddari, "Cérès et céréaliculture à travers le secteur méridional du Haut Tell tunisien”, XVII, 935-949.

As for Asclepius/Aesculapius and some others medical deities (Panakeia, Iatros, Hygia), see Claudio Parisi Presicce, "Panakeia, Iatros e le altre divinità asclepiadi a Cirene", IX, 147166; Nacéra Benseddik, "Esculape, Hygie et la IIIe légion Auguste”, XV, 1365-1372.

As for Oceanus, see Joëlle Napoli, "Le dieu Océan et l'expression des confins de la domination romaine: nouvelle lecture de la mosaïque de Thémétra”, XVI, 337-353.

As for Medusa, see Sebastián Vargas Vázquez, "El mito de Medusa en los mosaicos hispano-romanos", XVII, 2589-2599 and Guadalupe López Montegudo, "Perseo, viajero a Occidente. Documentos musivos", XIII, 145-157.

As for Sol Invictus, see Lamia Ben Abid, "Le culte du Soleil dans les provinces romaines d'Afrique", XIX, 2333-2363. 
As for mythology and religion, see María Pilar San Nicolás Pedraz, "Inscripciones latinas en los mosaicos mitológicos de Hispania y Norte de Africa”, IX, 1025-1037; José María Blázquez Martínez, "Mitos y leyendas homéricas en mosaicos de Hispania y del Norte de África”, XX, 413-428; María Luz Neira Jiménez, "Scylla como personificación del espacio tenebroso en el Mediterraneo antiguo", XIV, 261-269. For the Argonauts, see Giovanni Marginesu, "Il passaggio in Libye nelle tradizioni intorno agli Argonauti", XIII, 159-175; Mercedes Durán Penedo, "Dirce y Antiope: dos imágenes de valores contrapuestos del ciclo tebano en los mosaicos hispano-romanos", XVII, 1299-1322. For the Nereids and Nymphs, see María Luz Neira Jiménez, "Inscripciones con nombres de nereidas y ninfas en los mosaicos romanos del Norte de Africa y de Hispania”, IX, 1013-1023; Abdelaziz Bel Faïda, "Eau et sacré en Afrique romaine", XIV, 1715-1727; Adelina Arnaldi, "Osservazioni sul culto delle Nymphae nell'Africa romana”, XV, 1355-1364. For nymph cult buildings, see Corinne Sandoz, "Les nymphées de Lepcis Magna: aperçu préliminaire", XV, 1789-1808; Pilar Fernández Uriel, "Un ninfeo en Plaza de Armas (Melilla). Rusaddir, un núcleo púnico asimilado al modelo romano", XV, 1877-1883; Hakim Ammar, "A propos du nymphée de Sala”, XVII, 559-570.

As for the Genii, see Abdelaziz Bel Faïda, "Le culte des génies topiques dans l'Afrique romaine: témoignages épigraphiques”, XII, 1533-1554; Néjat Brahmi, “Textes et images du Genius en Maurétanie Tingitane”, XXI, 443-453.

As for the Manes, see Mauricio Pastor Muñoz, "Los Manes en la epigrafía funeraria de Mauretania Tingitana y Bética: diferencias y semejanzas", XVI, 1419-1438.

As for the calendar, see Ciro Parodo, "I Mamuralia del calendario figurato di Thysdrus: un caso di 'invented tradition'?", XX, 383-397.

On magic, see Santiago Montero, "Flora mágica africana”, XII, 387-400.

As for prodigies, see Miguel Requena and Juan José Seguí, “Deductio y prodigios en la fundación de Cartago por Cayo Graco", XVI, 2055-2067.

On priesthood, see Antonio Chausa, "El sacerdos maior de Lambaesis", XIII, 1441-1447; Jalel Mabrouk, "Le terme cultor dans l'épigraphie latine d'Afrique”, XXI, 403-413.

On epigraphic religious formulae, see Abdelaziz Belfaida, "Les formules ex visu et ex iussu dans l'épigraphie religieuse de l'Afrique Romaine", XIX, 2161-2171. On stele with iconography and religious content from the punic and numidian times to Roman one, see Elena Francesca Ghedini, "Ancora sulle stele della Ghorfa: qualche precisazione", VII, 233-244; Jean-Pierre Laporte, "Datation des stèles libyques figurées de Grande Kabylie”, IX, 389-423; Mohamed Kheir Orfali, "Notes sur quelques steles de tradition punique provenant de Tipasa”, XVII, 1993-2003; Bruno D’Andrea, “Continuità e rottura in Nord Africa nel passaggio dall'età punica all'età romana: l'esempio delle stele votive, tipologie formali, iconografie e iconologie”, XX, 197-214; see also Cinzia Rossignoli, "Persistenza del culto betilico nell'Africa romana: un' iscrizione da Thala (Tunisia)", IX, 73-96.

On funeral rites, see Lidiano Bacchielli, "Monumenti funerari a forma di cupula: origine e diffusione in Italia meridionale", III, 303-319; Giulia Baratta, "Alcune osservazioni sulla genesi e la diffusione delle cupae", XVI, 1669-1681. For some funerary mosaics see Kadria Fatima Kadra, "Nécropoles tardives de l'antique Theveste: mosaïques funeraires et mensae", 
VI, 265-282; Fathi Bèjaoui, “A propos des mosaiques funéraires d'Henchir Sokrine (environ de Lepti Minus, en Byzacène)", IX, 329-336.

On religious epigraphy of slaves and freedmen, see Denis Lengrand, "Les inscriptions votives paiennes des esclaves et des affranchis d'Afrique du Nord romaine”, XII, 959-972.

As for places of worship, temples and sanctuaries, see Silvia Bullo, "Le indicazioni di Vitruvio sulla localizzazione dei templi urbani (de Arch. I, 7,1): il caso africano”, X, 515-558; Cinzia Rossignoli, “Templi periurbani di Africa Proconsolare e Numidia: alcuni esempi”, X, 559-595; Silvia Bullo, Cinzia Rossignoli, "Il santuario rurale presso Bir bou Rekba (Thinussut): uno studio iconografico ed alcune riconsiderazioni di carattere architettonico-planimetrico", XII, 249-273; Patrizio Pensabene, "Sulla tecnica di lavorazione delle colonne del tempio tetrastilo di Thignica (Ain Tounga)", XI, 1103-1122 (the Thignica cases have been reexamined recently by Alessandro Teatini); Meriem Sebaï, "Les sanctuaries méridionaux du Cape Bon: 'une frontière religeuse'? Premières observations”, pp. 395-406; Wolfgang Kuhoff, "Presentazione del volume di J. Eingartner, Templa cum porticibus. Ausstattung und Funktion italischer Tempelbezirke in Nordafrika und ihre Bedeutung für die römische Stadt der Kaiserzeit", XVII, 49-51.

On the status of the land used to build temples, see Jalel Mabrouk, "Le statut des terrains des temples construits par les Thuggenses", XX, 467-482.

On altars, see Néjat Brahmi, "Les autels du culte domestique à Volubilis", XVII, 441459 , with the distinction of sacred spaces inside the domus.

On luci, see Salim Annane, "Inscription inédite de «LUCU» Timezouine (Saïda), Algérie", XXI, 425-431.

On divine epithets and divine attributes: Valentino Gasparini, "Chiamami col tuo nome. Una nuova proposta di analisi dell' impiego dei gentilizi come epiteti divini nell'epigrafia dell'Africa romana”, XXI, 385-394; Ridha Kaabia, “Epitheta deorum et richesse agricole en Afrique Romaine", XVII, 291-305.

On "paganism", important studies are dedicated to general aspects and individual cities: Khadidija Mansouri, "Le paganisme dans les colonies de la Confédération Cirtéenne à travers l'épigraphie", XVI, 1759-1784; Mariangela Pisanu, "La vita religiosa a Gigthis: testimonianze epigrafiche e monumentali", VII, 223-231.

On religious geography, see Matthew M. McCarty, "Réseaux d'idées: routes romaines et géographie religieuse de l'Afrique”, XVIII, 835-850. More specifically, for individual localities: René Rebuffat, "Divinités de l'oued Kebir (Tripolitaine)”, VII, 119-159; Véronique Brouquier-Reddé, Abdelaziz El Khayari, Adelfattah Ichkhakh, "Le temple du forum de Banasa: nouvelles données archéologiques", XV, 1885-1898; Sidi Mohammed Alaioud, "La vie religieuse à Banasa: témoignages archéologiques”, XVII, 549-558; Veronique Brouquier-Reddé, Abdelaziz El Khayari, Abdelfattah Ichkhakh, "Lixus, de l'époque phénicienne à la période médiévale: le quartier dit 'des temples”, XVI, 2157-2173. See also Maria Milvia Morciano, "Le trasformazioni dei segni del potere nella città di Tipasa di Mauretania. Assetto del territorio, viabilità, edifici pubblici e di culto", XIX, 515-525. 
As for the imperial cult, see Arbia Hilali, "Les affranchis et le culte de la gens Augusta: le témoignage de P. Perelius Hedulus à Carthage", XXI, 195-203; Francesca Cenerini, "Il culto di Livia Augusta tra Cirta e Leptis Magna", XVII, 2233-2242; Néjat Brahmi, "Genius et numen: deux manifestations du culte impérial à Volubilis", XVI, 2183-2199. On the buildings of the imperial cult: Patrizio Pensabene, "Il tempio della Gens Septimia a Cuicul (Gemila)", IX, 771-802; Patrizio Pensabene, "Gli spazi del culto imperiale nell'Africa Romana", X, 153-168; David L. Stone, "Coloni and the Imperial Cult in the Countryside of Sitifis", XVII, 2157-2170; Néjat Brahmi, "Les cultores Domus Augustae et le temple du culte impérial à Volubilis", XVIII, 1529-1541. Regarding the relation between the imperial cult and the Augustan deities, see Adelina Arnaldi, "Il culto delle divinità Augustae e i seviri nella documentazione epigrafica della Mauretania Tingitana", XVI, 1695-1705; Adelina Arnaldi, "Osservazioni sul flaminato dei Divi nelle province africane", XVIII, 1645-1665; Layla Es-Sadra, "La Domus Augusta de Volubilis et le temple du culte impérial", XXI, 375-384. About statuary: Mario Cesarano, "Dal paesaggio fisico al paesaggio ideologico. I cicli statuari dinastici giulio-claudii dell'Africa settentrionale", XIX, 257-268. The military ceremony of the Castellum Tamudense has been examined by M. Speidel, "The cereus of Tamuda", IX, 503-505; René Rebuffat, "L'offrande du décurion à Tamuda", XII, 1163-1171. See also Elizabeth Smadja, "Dépendance et culte impérial en Afrique", XII, 973-983; Sabino Perea, "El praefectus sacrorum, en ciudades de Africa e Hispania: un sacerdote del culto imperial?”, XII, 1441-1456; Leïla Ladjimi Sebaï, "Un texte votif en l'honneur de Commode sur une inscription inédite provenant de Mididi (Hr Midid-Tunisie)", XIII, 1543-1550; David Serrano Ordozgoiti, “Autorappresentazione imperiale della domus Licinia Augusta nell'epigrafia latina del Nord d'Africa (253-268 d.C.): una nuova sintesi", XXI, 93-104. On the priests of the imperial cult: Eva M. Morales Rodríguez, "Riflessioni sull'augustalità in Mauritania Tingitana. Le dediche ob honorem seviratus", XIX, 2061-2071. The imperial cult was already practiced in Mauretania under Claudius and was organized by Vespasian in a rather early period, immediately after the constitution of the province; this would be a further demonstration of the law according to which the less a country was romanized, the sooner the imperial cult was introduced, which above all in Africa has peculiar characteristics, perhaps determined by the punic or indigenous cultural remnants. Studies have been carried out on the continuation of the imperial cult in the $6^{\text {th }}$ century which was, however, addressed to a veneration of the person of the vandal kings. Studies on the imperial cult - which was introduced in Tingitana immediately after its annexation under Claudius, and was organized by Vespasian, in a rather early period compared to other provincial areas - have had a broader development. Some connection has been demonstrated and promoted by Juba II and Ptolemy, with the cult of the Moorish kings - attested until the $3^{\text {rd }}$ century - who considered themselves descendants of the mythical Antaeus. New data have been collected on the provincial organization of worship, on assemblies (concilia), on meeting places and on priesthood. The provincial context of the female flaminatus is explicitly documented 
in Volubilis for two flaminicae (no comparison with the other North African provinces). Among various forms of priesthood, the flaminatus documented already at the time of Claudius has aroused particular interest, thanks to the base of a statue in honor of $M$. Val(erius) Bostaris $f$. Severus, flamen primus in municipio suo (IAMar., lat. $448=A E$ 1978, 897); his wife, Fabia Bira Ilzeltae f(ilia), is repeatedly remembered as flaminica prima in municipio Vol(ubilitanorum). Other flaminicae are confirmed in Volubilis and Banasa. The list of the cultor(es) August(i) of Volubilis has been recovered, as well as the list of the Augustales. As for the seviri, their number has been confirmed ten of which five in Volubilis, three in Banasa, one in Sala and one in Lixus. Regarding the priesthood, an important study has been dedicated by Bassignano to the African flaminatus, with reference to individual cities and particular problems, such as the placement of the priesthood within the municipal career and the relation between urban and provincial flaminatus. In Thamugadi we might also outline a chronological evolution, given that in the high empire the flamines generally came from the equestrian order, whereas in the low empire this was not a requirement. According to Fishwick the title of flamen was replaced by that of sacerdos provinciae; Illuminati and Kotula have provided a list of provincial priests in Africa and Mauretania, focusing on the method regarding the election among the citizen legates who generally held perpetually the title of flamen. The rather small number of Augustales known in Africa (such as in Hippo Regius, in Thamugadi and above all in Theveste) cannot be explained by the particular socio-economic conditions and the scarcely developed craftsmanship; Kotula prefers to refer to the political and religious circumstances through which the imperial cult had affirmed itself in Africa. Above all the notable diffusion of the curiae (the Augustales were subordinated to the curiales) and, apparently, the limited number of slaves and consequently of freedmen might have contributed to the atrophy of augustality in Africa. The augustales of Thamugadi are remembered as ordo, as corpus and above all as holders of an arca, a public treasury; in this sense they are a re publica separati. Among some other types of priesthood, we will call attention to an augur attested at Tipasa, perhaps a native of Theveste. Chastagnol leads us to the final phase of our story in his article: André Chastagnol, "Sur les sacerdotales africains à la veille de l'invasion vandal", V, 101-110.

The way in which the African cults spread widely in the other provinces, in particular in Sardinia and in the Iberian provinces - but it goes as far as the territory of Dacia - has been extensively studied in recent years. As a mere example see María Cruz Marín Ceballos, María Belén Deamos, "De Cartago a Cádiz. Notas de iconografía religiosa", XVI, pp. 1461-1476; José Beltrán Fortes, José Manuel Rodríguez Hidalgo, “Dea Caelestis en Italica. Peculiaridades de un culto norteafricano en una ciudad de la Baetica”, XVI, 1439-1450; Mihai Barbulescu, "Africa e Dacia. Gli influssi africani nella religione romana della Dacia”, X, 1319-1338.

As for the so-called "Oriental cults", see Alberto Gavini, "I culti orientali in Zeugitana: «étude préliminaire»”, XVII, 2213-2231; Najoua Chebbi, “Ammon: identité, espace et populations", XX, 283-297. 
On Isis and Isis-Fortuna, see Serena Ensoli Vittozzi, "Indagini sul culto di Iside a Cirene", IX, 167-250; Darío Bernal Casasola, Javier del Hoyo Calleja, José Manuel Pérez Rivera, "Isis en Mauretania Tingitana: un nuevo testimonio epigrafico de su culto procedente de Septem Fratres (Ceuta)", XII, 1139-1161; Jean-Louis Podvin, "Lampes isiaques africaines: production et échanges", XVII, 2197-2211; Marta Bailón García, "Reflejos e influencias de los atributos de las divinidades norteafricanas en las diosas latinas: el caso de Isis-Fortuna”, XIX, 2985-2990.

On Serapis, see Johannes Eingartner, "Bemerkungen zur Funktion römischer Tempel am Beispiel des Isisheiligtums in Sabratha und des sogenannten Serapeion in Ephesos", XIII, 1211-1221; Nicola Bonacasa, Alessia Mistretta, "Sabratha sotterranea: ultime ricerche al Tempio di Serapide", XIX, 345-364.

On Mithras, see Abdelaziz Bel Faida, "Les cultes à mystères en Afrique du Nord antique. Le cas de Mithra: témoignages épigraphiques et archéologiques”, XXI, 433-442.

The aspects related to the Jewish and Christian world are extensively studied: we will limit ourselves to quoting the first articles, such as that of Clara Gebbia, "Le comunità giudaiche nell'Africa romana antica e tardoantica", III, 101-112; Clara Gebbia, "Ebrei nell'Africa romana: artigiani, agricoltori, commercianti”, XVIII, 881-888; Heikki Solin, "Gli Ebrei d'Africa: una nota", VIII, 615-623; Silvia Cappelletti, “CIL VIII 8499. La presenza ebraica in Mauretania", XVII, 1341-1349.

As for Christianity, we can begin with the slow transition from paganism to christianity: Stefano Conti, "Scambi culturali e persistenze: il paganesimo nell'Africa Proconsolare Cristiana", XVI, 883-897. Among the main studies: Liliane Ennabli, "Les inscriptions chrétiennes de Carthage et leur apport pour la la connaissance de la Carthage chrétienne", III, 189-204; Ingemar König, "Die frühe nordafricanische Kirche als Katalysator sozialen einheimischen Widerstandes gegen Rom?", VII, 363-373; Noël Duval, "Présentation du volume sur les Basiliques chrétiennes d'Algérie”, X, 101-104; Linda-Marie Günther, “Identità civile e patronato spirituale: cittadini cristiani nell'Africa tardo-imperiale", X, 769-777; Fathi Béjaoui, "Quelques nouveautés de l'épigraphie chrétienne de Tunisie", X, 677-684; Fathi Béjaoui, "Une nouvelle découverte d'époque chrétienne en Tunisie", VIII, 299303; Jean-Marie Lassère, "Miracles et vie économique en Afrique au Ve s. Á propos d'un troupeau de cochons (De miraculis Sancti Stephani protomartyris libri duo, I, 14), VIII, 305-312; Giovanna Maria Pintus, "Sacrifici animali e dèi di coccio (Arn., Adv. Nat. VII)", XI, 1629-1636; Barbara Giordani, "La basilica III di Sufetula”, XIV, 2059-2066.

Specific features related only to Africa are the phenomenon of Circumcelliones (Ilenia Achilli, "Circumcelliones, appunti sul fenomeno del 'monachesimo' itinerante", XVI, 923-933) and Donatism (Giovanni Alberto Cecconi, "Il 'Praedestinatus' (I 69) come fonte sul donatismo", IX, 865-879); as for monasticism see Claudia Neri, "Gli uomini di Dio ai confini del mondo: i monaci e il deserto", XV, 709-721; Claudia Neri, "Rendite private e donazioni di beni nel cenobitismo africano", XVII, 1127-1138; Carmen Alessandra Russo, "Insediamenti cenobitici e trasformazione del paesaggio nell'Africa tardoantica”, XIX, 905-917. 
Among the great ones of the African Church we will now only mention Tertullian (Maria Martha Pimentel de Mello, "Los dioses paganos en el Apologeticum de Tertuliano", VI, 625-642), some martyrs according to Jakko Aronen ("Pythia Carthaginis o immagini cristiane nella visione di Perpetua?”, VI, 643-648), Cyprian (Ridha Kaabia, "La typologie du mouvement des personnes dans la correspondance de Cyprien de Carthage", XVI, 935943; Domenica Lavalle, "Cipriano: il ruolo del vescovo e l'organizzazione delle comunità cristiane nell'Africa Proconsolare”, XIX, 875-885). See also Elena Caliri, "La penuria cultorum nel patrimonio ecclesiastico africano in età gregoriana e l'utilizzazione dei daticii", XVII, 1139-1149.

Reaching up to the Vandal age, see Serge Lancel, "Victor de Vita et la Carthage vandale", VI, 649-662; Federico Mario Beltrán Torreira, "La Iglesia norteafricana y el problema de la cristianizacion de los pueblos indigenas en la época vandala”, VII, 375-391.

We will focus on the figure of Augustine of Thagaste, which has been extensively studied, starting with the $6^{\text {th }}$ volume, specifically conceived to define the main aspects of the theme, with the interventions of Paolo Siniscalco, "Agostino, l'Africa e la Sardegna", VI, 535-546; Georges Folliet, "Fulgence de Ruspe, témoin privilégié de l'influence d’Augustin en Sardaigne", VI, 561-570; Pietro Meloni, "La vita monastica in Africa ed in Sardegna nel VI secolo sulle orme di S. Agostino", VI, 571-882; Luciano Marco Gastoni, "Le reliquie di S. Agostino in Sardegna", VI, 583-594; Anna Saiu Deidda, "Il santuario sotterraneo di S. Agostino nel contesto dell'architettura medioevale a Cagliari”, VI, 595-612; Marcella Bonello Lai, "Su alcuni frammenti di iscrizioni conservate all'interno del santuario sotterraneo di S. Agostino a Cagliari”, VI, 613-624; Clara Gebbia, "Sant'Agostino e l'episcopalis audientia", VI, 683-696; Pierre Salama, "La parabole des milliaires chez Saint Augustin”, VI, 697-708. In subsequent volumes, also thanks to new, important discoveries, see Konrad Vössing, "Augustins Schullaufbahn und das sog. dreistufige Bildungssystem", IX, 881-900; Antonio Sartori, "Le pere di Agostino: ecologia e santità tra Africa e Italia", XII, 439-445; Gabriele Marasco, "Agostino e l'aruspice di Cartagine", XII, 1555-1562; Giovanni Alberto Cecconi, "Donatismo e antidonatismo in Agostino alla luce dei sermoni 'Dolbeau”, XIII, 1819-1835; Christophe Hugoniot, "Les légats du proconsul d'Afrique à la fin du IVe siècle et au début du Ve ap. J.-C. à la lumière des sermons et lettres d'Augustin”, XIV, 2067-2087; Catherine

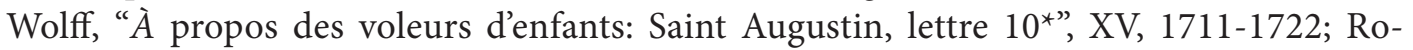
salba Arcuri, "Agostino e il movimento dei pellegrini verso l’Africa romana”, XVI, 945-957; Duilio Franchina, "I notarii in Agostino", XVIII, 1003-1020; Lietta De Salvo, "Gli spazi del potere ecclesiastico nella Ippona di Agostino", XIX, 1035-1051; Claudia Neri, "Alcuni esempi della trasformazione dei paesaggi "umani" rurali e urbani nelle epistole di Agostino", XIX, 1053-1061; Duilio Franchina, "Il controllo del territorio da parte dei vescovi tra la fine del IV e l'inizio del V secolo: l'esperienza di Agostino di Ippona”, XIX, 10771088; Manuel Rodríguez Gervás, "Territorialidad y centralidad en Agustín de Hipona”, XIX, 1089-1098; Mustapha Lakhlif, "Saint Augustin et l'incident de 411 à Hippone”, XIX, 1099-1107; Nacéra Benseddik, "Au pays d'Augustin. Nouvelles traces du christianisme antique", XIX, 1109-1122; Thomas Villey, "Les conversions de juifs au christianisme en Afrique d'après le témoignage de saint Augustin”, XX, 1127-1133. 
As for the end of the story, just as minimal example, see Hassan Limane, Elizabeth Fentress, "Nouvelles données archéologiques sur l'occupation islamique à Volubilis", XVI, 22192240 and the synthesis of Sanaa Hassab and Moukraenta Bakhta, "Le fait urbain au Maghreb entre l'époque romaine et l'époque islamique", XIX, 819-850.

\section{L'Africa romana}

Atti del I convegno di studio Sassari 16-17 dicembre 1983

a cura di Attilio Mastino

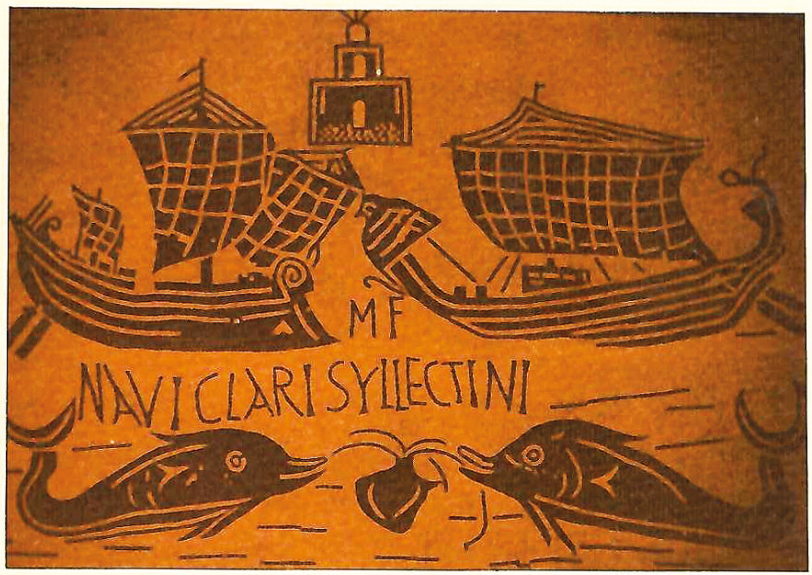

Edizioni Gallizzi 